Oleksii G. Lebid, $\mathrm{PhD}$, Senior Researcher

ORCID: 0000-0002-4003-8068,e-mail: o.g.lebid@ gmail.com

Institute of Telecommunications and Global Information Space of NASU, Kyiv, Ukraine

\title{
FIVE-MODE QUASILINEAR MODEL OF NONLINEAR DYNAMICS OF EXTENDED SYSTEM
}

\begin{abstract}
Distributed systems are widely used in practice. These are cosmic ligaments in the near-Earth space with a length of tens of kilometers. They approximate reinforced concrete piles in the soil when calculating the stress-strain state and assessing the technical condition; pipelines both in air and in liquid, underwater towed systems. Known underwater airlift systems of great length for the extraction of minerals (nodules) from the ocean floor with a length of 5-10 km. To solve the problems of the dynamics of such systems in various environments, the well-known mathematical models are not quite correct from the point of view of taking into account the variety of wave processes. It determines the need to build refined wave models. A new quasilinear mathematical model, which describes the nonlinear four-mode dynamics of the distributed system in the spatially inhomogeneous field of mass and surface forces, has been obtained. It is described by a nonlinear system of twelve first-order partial differential equations. For it, the principles of ultimate and hyperbolicity are fulfilled. Together with the boundary and initial conditions, it can be used to describe dynamics and statics of geometrically and physically nonlinear rod elements, piles in the ground, crane equipment ropes, mine lifts, aerial cableways, towed systems in liquid and gas flow, etc. For two-mode spatial reduction of the model, the theorem about correctness of Cauchy problem has been considered. As a result of the calculations, the earlier assumptions about the movement of the cable along its initial configuration were changed as the length of the cable changed. It has been found out that this assumption is only true for the initial transition participant. It is also established that at a given tachogram in the configuration of the towed line, there is a point of inflection, which shifts from top to bottom when lifting it. It can be a factor in the looping, contributing to the breakage of the cable system during towing.

Keywords: mathematical modeling; extended systems; waves; finite difference method; looping
\end{abstract}

(C) О.Г. Лебідь, 2021 


\title{
О.Г. Лебідь
}

Інститут телекомунікацій і глобального інформаційного простору НАНУ, м. Київ, Україна

\section{П'ЯТИМОДОВА КВАЗІЛІНІЙНА МОДЕЛЬ НЕЛІНІЙНОЇ ДИНАМІКИ ПРОТЯЖНОЇ СИСТЕМИ}

\begin{abstract}
Анотація. Розподілені системи знайшли широке застосування на практиці. Це космічні зв'язки у навколоземному просторі протяжністю в десятки кілометрів. Ними описуються залізобетонні палі в трунті при розрахунках напружено-деформованого стану й очінці технічного стану; трубопроводи як в повітрі, так $і$ в рідині; підводні буксирувані системи. Відомі підводні системи ерліфта великої протяжності для видобутку мінералів (конкрецій) з дна океану протяжністю в 5-10 км. Для вирімення завдань динаміки таких систем в різних середовищах відомі математичні моделі $\epsilon$ не цілком коректними з точки зору врахування різноманіття хвильових процесів. Це визначає необхіність побудови уточнених хвильових моделей. У статті отримана нова квазілінійна математична модель, що описує нелінійну чотирьохмодову динаміку розподіленої системи в просторово-неоднорідному полі масових $i$ поверхневих сил. Вона описується нелінійною системою дванадияти рівнянь першого порядку в часткових похідних. Для неї виконуються принципи граничності $i$ гіперболічності. $У$ сукупності з крайовими і початковими умовами модель може застосовуватися для опису динаміки і статики геометрично і фізично нелінійних стрижневих елементів, паль в трунті, канатів кранового обладнання, шахтних підйомників, підвісних канатних доріг, систем щуо буксируються в потоці рідини $і$ газу, ін. Для двохмодової просторової редукиї моделі розглянута теорема про коректність задачі Коші. Апробачія моделі проведена на основі чисельного рішення просторової задачі про поширення чотирьох хвиль трьох типів: поздовжніх, конфігураційних в напрямку нормалі і бінормалі, крутильних. 3 а допомогою чисельного алгоритму $і$ програми на основі методу скінченних різниць уточнені більш ранні припущення щзодо руху кабелю вздовж початкової конфігурації буксируваної лінії при зміні його довжини. 3'ясувалося, що це припущення вірне лище для початкової перехідної ділянки. Встановлено також, щңо при заданій тахограмі в конфігурації буксируваної лінії спостерігається точка перегину, яка змімується зверху вниз при підйомі кабелю. Це може бути чинником, щуо сприяє обриву кабельної системи та петлеутворенню при буксируванні.
\end{abstract}

Ключові слова: математичне моделювання; протяжні системи; хвилі; метод скінченних різниць; петлеутворення

DOI: 10.32347/2411-4049.2021.2.104-120

\section{Ветуп}

В даний час для проведення досліджень наукового, прикладного та військового характеру в космічному, повітряному і водному середовищах створюються і широко експлуатуються різні робототехнічні засоби, одним 3 основних елементів яких є протяжні системи (ПС) з фіксованою або змінною довжиною. Одним з цікавих застосувань є AN / ALE-50 [1]. AN / ALE-50 являє собою буксирувану пастку, яка використовує електронні засоби протидії, щоб заманити ракети, що наближаються, подалі від військових літаків (рис. 1). 


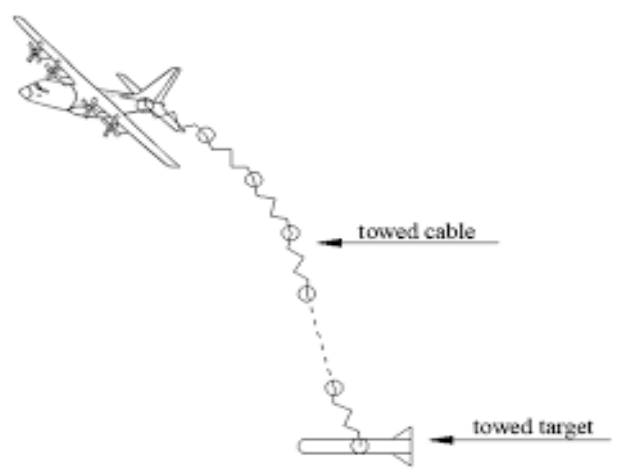

Рис. 1 - Загальний вид пастки (крупним планом) та літака, що буксирує пастку (на задньому плані) [1]

Пастка була створена в рамках спільного підприємства ВВС США, ВМС США i Raytheon. Пастка працює, створюючи більшу пляму на екрані радара протиповітряної оборони, ніж літак. Це робить ії більш пріоритетною метою для системи наведення ракети, що наближається. Такі пастки захищали літаки від ракетних загроз при бойових операціях в Косово, Афганістані та Іраку. Систему можна використовувати практично на будь-якій бортовій платформі бойових літаків, що стоять на озброєнні США і НАТО. Пастка активно використовується на літаках F-16, F/A-18E/F і В-1B. Загальна кількість пасток, що створені на даний час, перевищує 25000 штук [1]. При розгортанні пастка буксирується за літаком-господарем, захищаючи літак і його екіпаж від ракет 3 радіочастотним наведенням, заманюючи ракету в бік помилкової мети і від наміченої мети. Як в льотних випробуваннях, так і в реальних бойових умовах ALE-50 успішно відбивав численні бойові стрільби ракетами класу «земля повітря» і «повітря - повітря». Американські військові льотчики прозвали пастку «Маленький приятель» (рис. 2) [1].

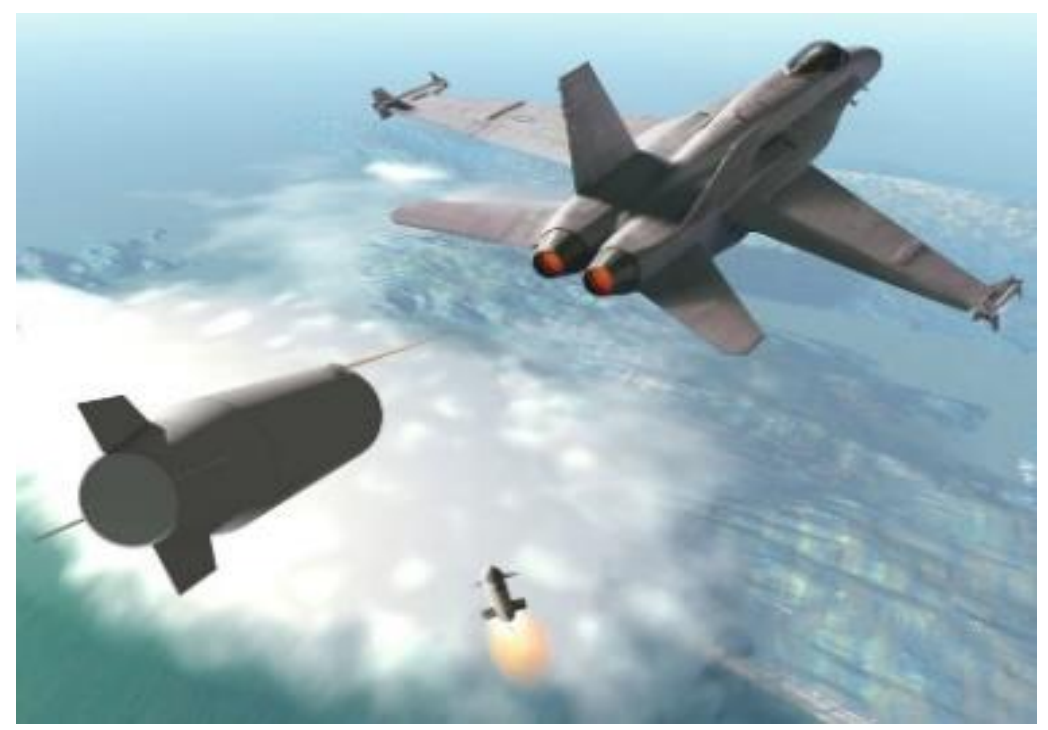

Рис. 2 - Протиповітряна ракета прямує в «Маленького приятеля». Сам літак залишається неушкодженим [1] 
На рис. 3 і 4 показано застосування ПС в підводних й космічних середовищах. При розробці морських вітряних електростанцій ПС (підводні кабелі) є необхідними в якості засобів передачі енергії для з'єднання морських вітряних електростанцій і берегових підстанцій. Осьові сили є однією 3 основних причин пошкодження ПС (підводних кабелів), які складаються із спіральної броні, оболонки, ізоляції та проводів. На додаток до осьового подовження, коли кабель піддається розтягуючим навантаженням, спіральна броня також створює крутний момент. У глибоководних умовах вплив тиску води на жорсткість кабелю $є$ важливим. В минулому такі дослідження проводилися рідко [2]. Коли кабель розташований на 4000 м нижче рівня моря, пов'язані розтягуючі, скручуючі і стискаючі навантаження можуть знизити жорсткість на розтяг ПС в цілому до 30\%. Таким чином, при аналізі і проектуванні ПС (підводних кабелів) необхідно ретельно враховувати пов'язані ефекти навантажень: розтягування, скручування і стискання [2].

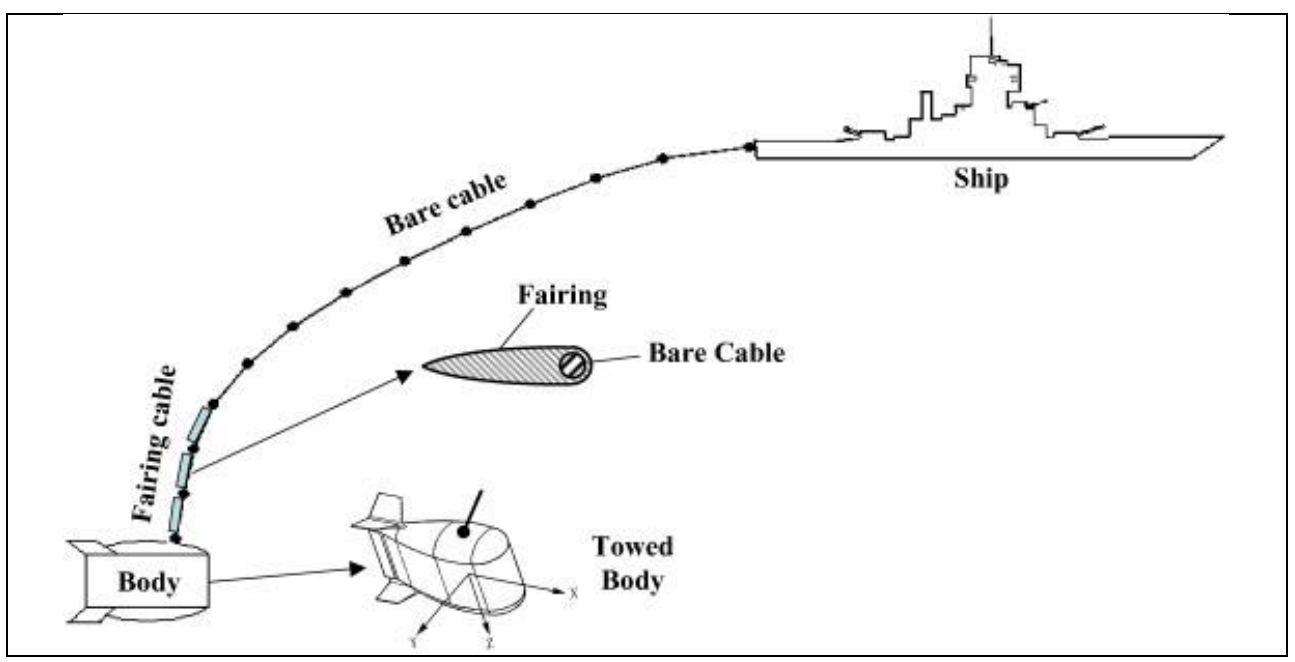

Рис. 3 - Буксирувана в потоці рідини ПС [3]

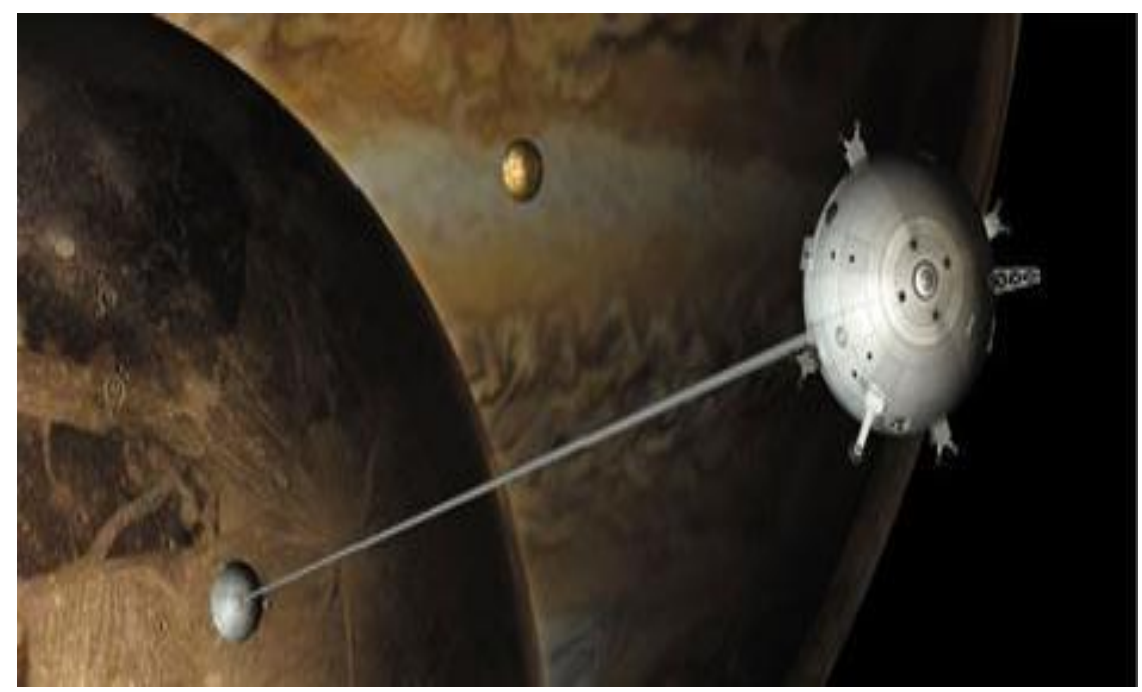

Рис. 4 - Космічні зв'язки [4] 
Обертові ПС (стрижні) є елементами лопатей вертольотів, маніпуляторів, робочих лопаток парових і газових турбін, лопатей повітряних гвинтів (рис. 5).

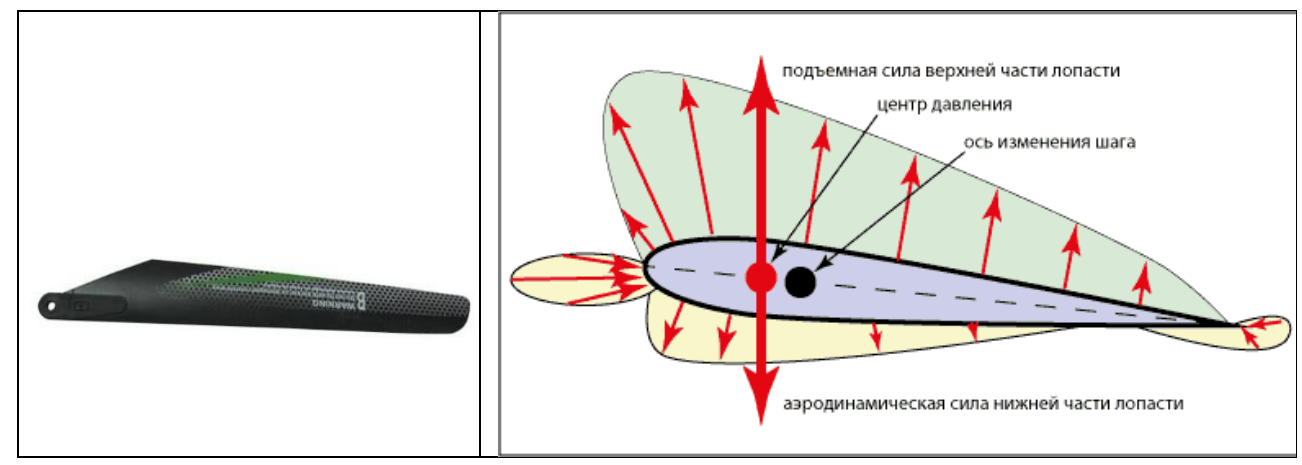

Рис. 5 - Вертолітна лопать та механізм створення підйомної сили

В експлуатації такі стрижневі конструкції часто здійснюють коливання, які можуть зумовити втомні пошкодження. Дослідження коливань цих систем ускладнюється тим, що вони мають несиметричний поперечний переріз. У цьому випадку центр ваги i центр вигину поперечного перерізу не збігаються. Здійснювалися спроби дослідження нелінійних коливань стрижнів 3 несиметричним поперечним перерізом. С.П. Тимошенко [5] отримав рівняння лінійних згинально-крутильних коливань прямих незакручених стрижнів з несиметричним поперечним перерізом. У роботах $[6,7]$ були отримані рівняння лінійних згинально-згинально-крутильно-поздовжніх коливань закручених обертових стрижнів 3 урахуванням депланації поперечного перерізу при зсуві і крученні.

У [8] представлена система рівнянь в часткових похідних, що описує геометрично нелінійні згинально-згинально-крутильно-поздовжні коливання обертового стрижня. У цих рівняннях враховувалося, що центр ваги поперечного перерізу i центр жорсткості знаходяться в одній точці. У [8] отримані рівняння, що описують згинально-згинально-крутильні коливання стержня з урахуванням нерозтяжності серединної лінії ПС. При цьому передбачалося, що центр ваги поперечного перерізу і центр жорсткості знаходяться в одній точці.

Систематичний виклад теорії гнучких стрижнів міститься в монографії [6]. В роботі [9] представлена система трьох нелінійних інтегро-диференціальних рівнянь в часткових похідних, що описує згинально-згинально-крутильні коливання гнучкого обертового стрижня 3 урахуванням депланації поперечного перерізу. В [10] відзначається, що для дискретизації системи коливання розкладаються у ряд за власними формами лінійної задачі. Вільні коливання досліджуються за допомогою нелінійних нормальних форм Шоу П'єра. В результаті аналізу отримано вплив депланації ПС на їх коливання. Урахування депланації ПС призводить до переважного внеску нелінійної інерційності в коливання стрижня, а навпаки, неврахування депланації, - до геометричної нелінійності.

У той же час отримана авторами [10] система рівнянь для алгоритмізації і рішення геометрично і фізично нелінійних задач $є$ слабо пристосованою, за іiі допомогою можливо отримати рішення тільки для окремих випадків. 
Авторами [10] виконано тільки спрощений аналіз отриманої системи рівнянь шляхом ii дискретизації, де коливання розкладаються у ряд за власними формами лінійної задачі і тільки для окремого випадку.

Незважаючи на численні дослідження, проведені в області вивчення статики і динаміки ПС, неясними залишаються багато особливостей їх поведінки: проблеми в діагностиці цілісності паль (каверни, шийки, розширення і т.д.), петлеутворення в ПС при буксируванні в космосі, повітрі та водному середовищі, правильний вибір коефіцієнта динамічності при складних маневрах буксирувальника і т.д. Окремим питанням, що вимагає досліджень в області побудови алгоритмів розпаралелювання і паралельних обчислень, є врахування багатохвильового характеру розповсюдження збурень в ПС. Традиційні обчислення напружено-деформованого стану (НДС) ПС на основі спрощених математичних моделей часто призводять до «розхитування» обчислювальних алгоритмів i невірних висновків при інтерпретації отриманих чисельних даних, як показано в роботах Трофимчука О.М., Калікова В.М., Ордановича О.С. та ін. У роботі Селезова I.T. показано, що рівняння Тимошенка принципово відрізняється від класичного рівняння Бернуллі - Ейлера згинних коливань балки. Воно описує поширення збурень зі скінченною швидкістю, що встановлено із узагальненого рівняння 6-го порядку гіперболічного типу, яке як часткові випадки включає відомі рівняння, а також рівняння Тимошенка без коректуючого коефіцієнта зсуву. Селезовим I.T. відмічається, що у подальшому було розроблено обчислювальні програми, але із порушеннями суцільності середовища, тобто спрощенням моделі [11].

Як об'єкти математичного моделювання ПС описуються системами квазілінійних рівнянь. Чисельне моделювання нелінійних систем в умовах сьогодення $\epsilon$ окремим напрямком в математичній царині. Серед робіт, присвячених побудові складних математичних моделей процесів механіки деформованого середовища, гідродинаміки та фільтрації підземних вод, слід виділити праці Сергієнка I.В., Скопецького В.В., Трофимчука О.М., Губарева В.Ф., Калюха Ю.І. та ін. В розвиток нестаціонарних задач аерогідропружного НДС ПС, розробку рішення статичних, динамічних та оптимізаційних задач значний внесок здійснили Крилов О.М., Тимошенко С.П., Ішлінський А.Ю., Селезов І.Т., Кубенко В.Д., Горошко О.О., Каюк Я.Ф., Гузь О.М., Салтанов М.В., Горбань В.О., Орданович О.Є., Калюх Ю.І., Каліков В.М., Гуляєв В.I., Гайдачук В.В., Кошкін В.Л., Баженов В.О., Лізунов П.П., Попов Е.П., Ілюхін О.А., та ін. Вагомі результати в області вирішення прикладних задач статики, динаміки та оптимізації ПС отримані Ядикіним Ю.В., Безверхим А.І., Тихоновим В.С., Некрасовим I.В., Ремчуковим В.I., Поддубним В.І., Ільїним Р.Ф. та ін. [12-20]. Серед зарубіжних вчених, які зробили значний внесок в аналіз статики і динаміки ПС в потоці, необхідно виділити Chapman B.A., Griffin O.M., Iwers W.B., Nair S., Wingham B.S. та ін.

Питанням удосконалення методів розрахунку та розробки програмних засобів для комп'ютерної реалізації розрахунків ПС у будівництві, впровадження заходів 3 проектування та влаштування протизсувних споруд з ПС у вигляді паль присвячено багато наукових робіт та досліджень, серед яких найбільш відомими є праці Трофимчука О.М., Калюха Ю.І., Бойка В.В., Герсенванова М.М., Гольдштейна М.М., Гінзбурга Л.К., Кільвандера Є.Я., 
Маслова М.М., Полевецького В.В., Сільченка К.В., Шахунянца Г.М., Чернія Г.І., Глуховського В.П., Яраса В.І., Улицького В.М., Джонса Р., Фекеоару I., Лещинського М.Ю., Єрмошкіна П.М., Ногіна С.I., Сафарова В.А., Судакова В.В., Почтовика Г.Я., Бамбури А.М., Городжи А.Д., Мар'єнкова М.Г., Немчинова Ю.І., Довженко О.O., Bishop A., Fellenius W., Fukoka H., Mongerstern N., Sassa K., Terzaghi K., Carino N.J., Sansalone M., Hsu N.N., Lin J.-M., Streett W., Liao S.T., Roesset J.M., Chen C.H., Yu C.P., Ambrosini D., Ezeberry J., Kim D.S., Kim H.W., Kim W.C., Seo W.S., Choi K.C., Wooa S.K. та ін. [12-20].

При спробі вдосконалення математичного моделювання розподілених ПС виникає низка складнощів, що обумовлені відсутністю ефективних програмних засобів комп'ютерного моделювання, недосконалістю та обмеженістю прикладних методик для розрахунку хвильового НДС ПС. Головними недоліками є відсутність та недостатня розробленість нелінійних хвильових динамічних математичних моделей ПС, досконалих методів їх чисельного моделювання, що $є$ перепонами для створення на їх базі сучасних експериментальних автоматизованих комп'ютерних приладів неруйнівної діагностики безпосередньо в умовах будівельних майданчиків при зведенні будівель та споруд.

П'ятихвильова модель динаміки ПС. Розглянемо ПС у просторі 3 постійними характеристиками поперечного перерізу. Радіус-вектор початкового положення стрижня позначимо $\bar{R}_{0}(S, 0)$, а деформованого $\bar{R}(S, t)$.

Введемо деформацію елемента ПС:

$$
\varepsilon=\frac{\left(\mathrm{d} S^{2}-d S_{0}^{2}\right)}{d S_{0}^{2}}=\left|\frac{\partial \bar{R}}{\partial S}\right|^{2}-1 .
$$

Тоді змінні $S_{0}$ i $S$, що характеризують недеформовану та розтягнуту довжину ПС, будуть пов'язані між собою співвідношенням:

$$
d S=\sqrt{1+\varepsilon} \cdot d S_{0}
$$

Введемо поперечну деформацію (депланація) елемента ПС, що описує рівномірне стиснення - розширення його поперечного перерізу.

Введемо природну систему координат 3 одиничними взаємоортогональними векторами $\overline{\mathrm{t}}, \overline{\mathrm{n}} \mathrm{i} \overline{\mathrm{b}}$. Вектор $\overline{\mathrm{t}}-$ одиничний вектор дотичної, визначається зі співвідношення:

$$
\vec{t}(S, t)=\frac{\partial \bar{R}(S, t)}{\partial S},
$$

а два інших вектори $-\overline{\mathrm{n}}$ i $\overline{\mathrm{b}}-$ ортогональні до $\overline{\mathrm{t}}$. Похідна радіус-вектора $\overline{\mathrm{R}}$ в деформованому стані має вигляд

$$
\frac{\partial \bar{R}}{\partial S}=\bar{t}(1+\varepsilon) .
$$


3 іншого боку, для похідної від радіус-вектора $\bar{R}(S, t)-\partial \bar{R} / \partial t-$ маємо такий вираз:

$$
\frac{\partial \bar{R}}{\partial t}=U_{t} \bar{t}+U_{n} \bar{n}+U_{b} \bar{b}
$$

Тут $U_{t}, U_{n}$ і $U_{b}-$ проекції відносної швидкості на поточні одиничні вектори $\overline{\mathrm{t}}, \overline{\mathrm{n}} \mathrm{i} \overline{\mathrm{b}}$.

Якщо долучити умови безперервності, існування похідних від радіусвектора $\overline{\mathrm{R}}(\mathrm{S}, \mathrm{t})$ необхідного порядку та рівності змішаних похідних, то можемо отримати наступні вирази

$$
\frac{\partial \varepsilon}{\partial t}=\frac{\partial U_{t}}{\partial S}-k_{1} U_{n}-k_{2} U_{b} ;-(1+\varepsilon) \Omega_{1}=\frac{\partial \mathrm{U}_{\mathrm{b}}}{\partial \mathrm{S}}-\mathrm{k}_{2} \mathrm{U}_{\mathrm{t}}+\mathrm{k}_{3} \mathrm{U}_{\mathrm{n}} ;(1+\varepsilon) \Omega_{2}=\frac{\partial \mathrm{U}_{\mathrm{n}}}{\partial \mathrm{S}}+\mathrm{k}_{1} \mathrm{U}_{\mathrm{t}}+\mathrm{k}_{3} \mathrm{U}_{\mathrm{b}}
$$

Повні похідні кривизни $\mathrm{k}_{\mathrm{i}}$ за часом мають вигляд:

$$
\frac{\partial \mathrm{k}_{3}}{\partial \mathrm{t}}=\frac{\partial}{\partial \mathrm{t}}\left(\frac{\partial \overline{\mathrm{n}}}{\partial \mathrm{S}} \overline{\mathrm{b}}\right)=\frac{\partial \mathrm{b}}{\partial \mathrm{t}} \frac{\partial \overline{\mathrm{n}}}{\partial \mathrm{S}}+\overline{\mathrm{b}}\left(\frac{\partial^{2} \overline{\mathrm{n}}}{\partial \mathrm{S} \partial \mathrm{t}}-\frac{\partial \varepsilon}{\partial \mathrm{t}} \frac{\partial \overline{\mathrm{n}}}{\partial \mathrm{S}} \frac{1}{1+\varepsilon}\right)
$$

або:

$$
\frac{\partial \mathrm{k}_{3}}{\partial \mathrm{t}}=\frac{\partial \Omega_{3}}{\partial \mathrm{S}}-\mathrm{k}_{1} \Omega_{1}-\mathrm{k}_{2} \Omega_{2}-\frac{\mathrm{k}_{3}}{1+\varepsilon} \frac{\partial \varepsilon}{\partial \mathrm{t}}
$$

За аналогією для $k_{1}$ i $k_{2}$ :

$$
\frac{\partial k_{1}}{\partial t}=\frac{\partial \Omega_{2}}{\partial S}+k_{2} \Omega_{3}+k_{3} \Omega_{1}-\frac{k_{1}}{1+\varepsilon} \frac{\partial \varepsilon}{\partial t} \frac{\partial k_{2}}{\partial t}=-\frac{\partial \Omega_{1}}{\partial S}+k_{3} \Omega_{2}+k_{1} \Omega_{3}-\frac{k_{2}}{1+\varepsilon} \frac{\partial \varepsilon}{\partial t} .
$$

Запишемо загальні теореми про збереження кількості руху і збереження моменту кількості руху для елемента ПС у векторній формі [21]:

$$
\frac{\partial \overline{\mathrm{N}}}{\partial \mathrm{S}}+\overline{\mathrm{F}}^{(\mathrm{E})}+\overline{\mathrm{F}}^{(\mathrm{I})}+\overline{\mathrm{F}}^{(\mathrm{M})}=0 ; \frac{\partial \bar{M}}{\partial S}+\bar{t} \times \bar{N}+\bar{M}^{(E)}+\bar{M}^{(I)}+\bar{M}^{(M)}=0 .
$$

Або в скалярному вигляді

$$
\begin{aligned}
& \frac{\partial \mathrm{N}_{1}}{\partial \mathrm{S}}+\mathrm{k}_{1} \mathrm{~N}_{3}-\mathrm{k}_{3} \mathrm{~N}_{2}+\overline{\mathrm{F}}^{(\mathrm{E})} \overline{\mathrm{n}}+\overline{\mathrm{F}}^{(\mathrm{I})} \overline{\mathrm{n}}+\overline{\mathrm{F}}^{(\mathrm{M})} \overline{\mathrm{n}}=0 . \\
& \frac{\partial \mathrm{N}_{2}}{\partial \mathrm{S}}+\mathrm{k}_{3} \mathrm{~N}_{1}+\mathrm{k}_{2} \mathrm{~N}_{3}+\overline{\mathrm{F}}^{(\mathrm{E})} \overline{\mathrm{b}}+\overline{\mathrm{F}}^{(\mathrm{I})} \overline{\mathrm{b}}+\overline{\mathrm{F}}^{(\mathrm{M})} \overline{\mathrm{b}}=0 . \\
& \frac{\partial \mathrm{N}_{3}}{\partial \mathrm{S}}-\mathrm{k}_{1} \mathrm{~N}_{1}-\mathrm{k}_{2} \mathrm{~N}_{2}+\overline{\mathrm{F}}^{(\mathrm{E})} \overline{\mathrm{t}}+\overline{\mathrm{F}}^{(\mathrm{I})} \overline{\mathrm{t}}+\overline{\mathrm{F}}^{(\mathrm{M})} \overline{\mathrm{t}}=0 .
\end{aligned}
$$

Із закону Гука для осьового зусилля для елемента ПС випливає:

$$
\mathrm{N}_{3}=\mathrm{EF} \varepsilon
$$


Тут E - модуль Юнга матеріалу ПC, F - площа поперечного перерізу ПС до деформації, $\varepsilon$ - відносна поздовжня деформація ПС.

Запишемо умови збереження моменту кількості руху в проекціях на одиничні взаємоортогональні вектори $\overline{\mathrm{t}}, \overline{\mathrm{n}} \mathrm{i} \overline{\mathrm{b}}$ прийнятої системи координат $[13,15]$ :

$$
\begin{aligned}
& \frac{\partial \mathbf{M}_{2}}{\partial \mathrm{S}}+\mathrm{k}_{3} \mathrm{M}_{1}-\mathrm{k}_{3} \mathrm{M}_{3}+\mathrm{N}_{1}+\overline{\mathrm{m}}^{(\mathrm{E})} \overline{\mathrm{b}}+\overline{\mathrm{m}}^{(\mathrm{I})} \overline{\mathrm{b}}+\overline{\mathrm{m}}^{(\mathrm{M})} \overline{\mathrm{b}}=0 ; \\
& \frac{\partial \mathrm{M}_{1}}{\partial \mathrm{S}}+\mathrm{k}_{1} \mathrm{M}_{3}-\mathrm{k}_{3} \mathrm{M}_{2}-\mathrm{N}_{2}+\overline{\mathrm{m}}^{(\mathrm{E})} \overline{\mathrm{n}}+\overline{\mathrm{m}}^{(\mathrm{I})} \overline{\mathrm{n}}+\overline{\mathrm{m}}^{(\mathrm{M})} \overline{\mathrm{n}}=0 ; \\
& \frac{\partial \mathrm{M}_{3}}{\partial \mathrm{S}}+\mathrm{k}_{1} \mathrm{M}_{1}-\mathrm{k}_{2} \mathrm{M}_{2}+\overline{\mathrm{m}}^{(\mathrm{E})} \overline{\mathrm{t}}+\overline{\mathrm{m}}^{(\mathrm{I})} \overline{\mathrm{t}}+\overline{\mathrm{m}}^{(\mathrm{M})} \overline{\mathrm{t}}=0 ;
\end{aligned}
$$

Для згинальних моментів $M_{1}, M_{2}$, а також $M_{3}$ приймемо співвідношення:

$$
\begin{aligned}
& M_{1}=-E I_{22} k_{2} ; \\
& M_{2}=E I_{11} k_{1} ; \\
& M_{3}=G J k ; k=k_{3}-\eta_{3} .
\end{aligned}
$$

Тут $I_{22}, I_{11}, J$ - моменти інерції, а $\eta_{3}$ - кут закручування одиниці довжини ПС.

Отримана система рівнянь (11)-(14) описує фізично та геометрично нелінійну просторову модель динаміки ПС. Однак вона $є$ параболічногіперболічною, так як не враховано інерцію повороту поперечного перерізу ПС. Модель (11)-(14) описує тільки чотири хвилі в ПС з шести (поздовжні, крутильні, згинальні (дві)), а конфігураційні (поперечні) хвилі не описує [21].

Для усунення цього недоліку гіперболізуємо модель (11)-(14) шляхом введення кутів $\alpha$ і $\beta$. Вони будуть характеризувати поворот поперечних перерізів ПС, тобто деформацію зсуву в усередненому сенсі. Поперечні перерізи, плоскі до деформації, залишаються такими ж плоскими і після деформації, але, можливо, повернутими. Причому не обов'язково перпендикулярними до серединної осі ПС. Матеріалізація цієї гіпотези для перерізуючих сил $N_{1}$ і $N_{2}$ набуває такого вигляду

$$
N_{1}=\alpha l_{1} G F_{s} ; \quad N_{2}=\beta l_{2} G F_{s} .
$$

Тут $l_{1}, l_{2}$ - коефіцієнти, що враховують вплив зсуву, $F_{s}$ - площа поперечного перерізу ПС.

У першому наближенні, під депланацією поперечного перерізу ПС будемо розуміти його рівномірне стиснення або розтягнення - змінна $z(t, S)$. Врахування депланації поперечного перерізу $z(t, S)$ при зсуві і крученні ПС зробимо на основі узагальненого хвильового рівняння, коефіцієнти якого залежать від $t, S$ й інших невідомих $U_{t}, U_{n}, U_{b}$ i $\Omega_{1}, \Omega_{2}, \Omega_{3}$.

$$
f_{1} \frac{\partial^{2} z}{\partial t^{2}}+f_{2} \frac{\partial^{2} z}{\partial t \partial S}+f_{3} \frac{\partial^{2} z}{\partial S^{2}}+f_{4} \frac{\partial z}{\partial t}+f_{5} \frac{\partial z}{\partial S}=P_{13} .
$$

Модель (11)-(14) з додатковою умовою (15) та гіперболічним рівнянням другого порядку (16), що описує хвильову депланацію поперечного перерізу ПС, можна шляхом нескладних тотожних перетворень записати: 
a) $\left\{\begin{array}{l}a_{11} \frac{\partial k_{1}}{\partial S}+a_{12} \frac{\partial \Omega_{1}}{\partial t}+a_{13} \frac{\partial \Omega_{2}}{\partial t}=P_{1} \\ a_{21} \frac{\partial k_{2}}{\partial S}+a_{22} \frac{\partial \Omega_{1}}{\partial t}+a_{23} \frac{\partial \Omega_{2}}{\partial t}=P_{2} \\ a_{31} \frac{\partial k_{3}}{\partial S}+a_{32} \frac{\partial \Omega_{3}}{\partial t}=P_{3}\end{array}\right.$

б)

$\left\{\begin{array}{l}a_{41} \frac{\partial k_{1}}{\partial t}+a_{42} \frac{\partial \Omega_{2}}{\partial S}=P_{4} \\ a_{51} \frac{\partial k_{2}}{\partial t}+a_{52} \frac{\partial \Omega_{1}}{\partial S}=P_{5} \\ a_{61} \frac{\partial k_{3}}{\partial t}+a_{62} \frac{\partial \Omega_{3}}{\partial S}=P_{6}\end{array}\right.$

B)

$\left\{\begin{array}{l}a_{71} \frac{\partial \alpha}{\partial S}+a_{72} \frac{\partial U_{n}}{\partial t}+a_{73} \frac{\partial N_{3}}{\partial t}=P_{7} \\ a_{81} \frac{\partial \beta}{\partial S}+a_{82} \frac{\partial U_{b}}{\partial t}+a_{83} \frac{\partial N_{3}}{\partial t}=P_{8} \\ a_{91} \frac{\partial N_{3}}{\partial S}+a_{92} \frac{\partial U_{t}}{\partial t}+a_{93} \frac{\partial N_{3}}{\partial t}=P_{9}\end{array}\right.$

г) $\left\{\begin{array}{l}a_{101} \frac{\partial \alpha}{\partial t}+a_{102} \frac{\partial U_{n}}{\partial S}=P_{10} \\ a_{111} \frac{\partial \beta}{\partial t}+a_{112} \frac{\partial U_{b}}{\partial S}=P_{11} ; \\ a_{121} \frac{\partial N_{3}}{\partial t}+a_{122} \frac{\partial U_{t}}{\partial S}=P_{12} .\end{array}\right.$

д) $f_{1} \frac{\partial^{2} z}{\partial t^{2}}+f_{2} \frac{\partial^{2} z}{\partial t \partial S}+f_{3} \frac{\partial^{2} z}{\partial S^{2}}+f_{4} \frac{\partial z}{\partial t}+f_{5} \frac{\partial z}{\partial S}=P_{13}$.

Система (17)-(21) являє собою систему квазілінійних гіперболічних рівнянь, що описує сім мод коливань ПС п’яти типів: поздовжні, крутильні, дві конфігураційні (поперечні) та дві згинальні, а також депланаційні.

Перші три рівняння (17) описують закон збереження моменту руху елементом ПС, друга група рівнянь (18) - динамічний зв'язок між нестаціонарними похідними від кривизни $k_{i}$ і конвективними похідними від кутових швидкостей $\Omega_{i}$. Разом система (17)-(18) описує три моди коливань згинальні у двох взаємоортогональних площинах $(\bar{n}, \bar{t}) \mathrm{i}(\bar{b}, \bar{t})$, а також крутильну.

Перші три рівняння (19) виражають динамічний закон збереження кількості руху елементом ПС, останні три рівняння (20) - умову «нерозривності» ПС:

$$
\frac{\partial^{2} \bar{R}}{\partial t \partial S}=\frac{\partial^{2} \bar{R}}{\partial S \partial t} .
$$

Разом рівняння (19)-(20) описують три моди коливань: конфігураційні (поперечні) в двох взаємоортогональних площинах $(\bar{n}, \bar{t}) \mathrm{i}(\bar{b}, \bar{t})$, а також поздовжню. 
Останнє рівняння (21) описує хвильову депланаційну зміну поперечного перерізу ПС в наближеному вигляді (у вигляді нестаціонарного рівномірного звуження або розширення поперечного перерізу ПС при проходженні через нього хвиль різних типів). Передбачається, що коефіцієнти в (21) при похідних $f_{i}, i=1,5$ та права частина $P_{13}$ залежать від вектора-стовпця невідомих $W$, компонент розподілених масових і поверхневих сил, що діють на ПС в потоці рідини (або газу).

У підсумку система рівнянь (17)-(21) може бути записана у вигляді одного матричного рівняння типу переносу в стандартній формі $[13,15]$ :

$$
E \frac{\partial W}{\partial t}+B \frac{\partial W}{\partial S}=P
$$

Тут $E$ - одинична матриця розмірності $14 \mathrm{x} 14, B$ - матриця конвективних членів $14 x 14$. Вектор-стовпець правих частин $P$ визначається розподіленими масовими та поверхневими силами, а також моментами цих сил. Векторстовпець $P$ залежить від часу $t$, лагранжевої координати $S$, вектора-стовпця невідомих $W$, компонент розподілених масових і поверхневих сил.

Крайові та початкові умови для моделі (22). У верхній частині ПС (при $S=L)$ можуть бути задані проекції швидкості $\bar{U}$ :

$$
\begin{aligned}
& U_{t}(L, t)=U_{t}^{*}(t) \\
& U_{n}(L, t)=U_{n}^{*}(t) \\
& U_{b}(L, t)=U_{b}^{*}(t)
\end{aligned}
$$

На нижньому кінці ПС (при $S=0$ ) можуть бути задані умови динамічної рівноваги сил $\bar{F}_{i}$ і моментів $\bar{M}_{j}$ на кінці ПС (наприклад, на транспортованому вантажеві (приладі) рис. 2-4):

$$
\sum_{i=1}^{3} \bar{F}_{i}=0 ; \quad \sum_{j=1}^{3} \bar{M}_{j}=0 .
$$

В якості вихідних умов використовується рішення задачі статики на основі моделі (22) при $\frac{\partial}{\partial t}(\ldots)=0$ [13]. Модель (22) з початковими та крайовими умовами (23)-(24) являє собою замкнуту систему квазілінійних рівнянь в часткових похідних, а також початково-крайову задачу.

Case Study моделі (22)-(24). Еволюція геометричних характеристик буксируваної системи при маневрі судна-буксирувальника. Розглянемо на конкретному прикладі еволюцію основних силових i геометричних характеристик буксируваної ПС при маневрі, що найбільш часто зустрічається на практиці [15]:

1. обхід буксированим апаратом перешкоди на дні;

2. маневр зондування у вертикальній площині безпілотним підводним апаратом (БПА) з метою пошуку донних мін та інших малорозмірних об'єктів, розміщених безпосередньо на морському дні (кабелі зв'язку, нафто- i газопроводи та ін.). 
Розглянемо маневр судна-буксирувальника 3 ПС та БПА, що швидко відбувається та здійснюється при постійній швидкості буксирування $7.5 \mathrm{M} / \mathrm{c}$ шляхом зміни довжини витравленої частини ПС. Первісна довжина системи становила 120 м, найбільша довжина під час еволюції була 175 м, час змотування змінювався в діапазоні $[0 \div 20$ с] в залежності від тахограми лебідки. Силові та гідродинамічні характеристики ПС були наступними: погонна маса і приєднана маса до деформування ПС - 2.5 та 0.8 кг/м, початковий діаметр канату - 0.03 м, первісна плавучість одиниці довжини канату - $17.6 \mathrm{H} / \mathrm{M}$, ефективна розтяжність канату змінювалася в діапазоні $\left[3 \times 10^{-6} \div 3 \times 10^{-8}\right]$, маса БПА - 250 кг (приєднана маса БПА - 50 кг), площа міделевого перетину БПА - $0.4 \mathrm{~m}^{2}$, гідродинамічний коефіцієнт опору БПА дорівнював 0.5 , гідродинамічні коефіцієнти опору форми і тертя ПС були, відповідно, 0.05 і 0.01, дискретність по довжині ПС змінювалася в діапазоні $[1 \div 20 \mathrm{M}]$, коефіцієнти $C_{1}$ i $C_{2}$ дорівнювали $C_{1}=0, C_{2}=5$, крок за часом вибирався з умови стійкості рахунку [15].

Чисельні результати були отримані для тахограми, в якій чергувалися два режими: витравлювання - підйом із зупинкою лебідки (рис. 6).

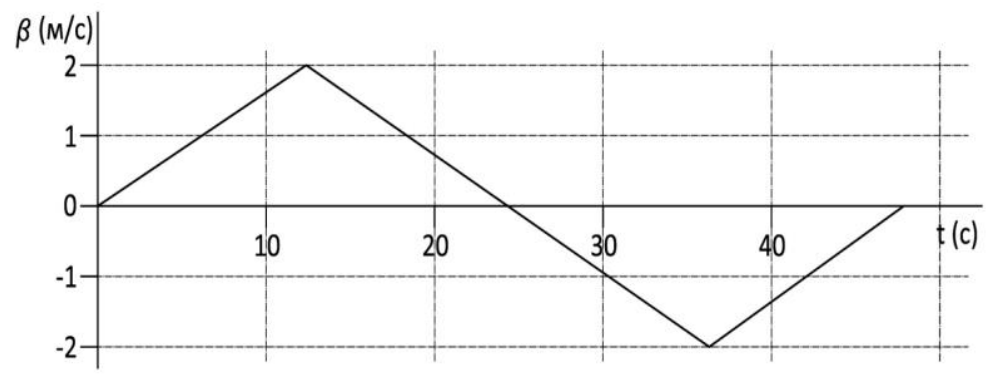

Рис. 6 - Тахограма режиму роботи лебідки

Еволюційні криві всієї конфігурації ПС для даної тахограми лебідки при швидкості буксирування 4 м/с в різні моменти часу зображені на рис. 7-8.

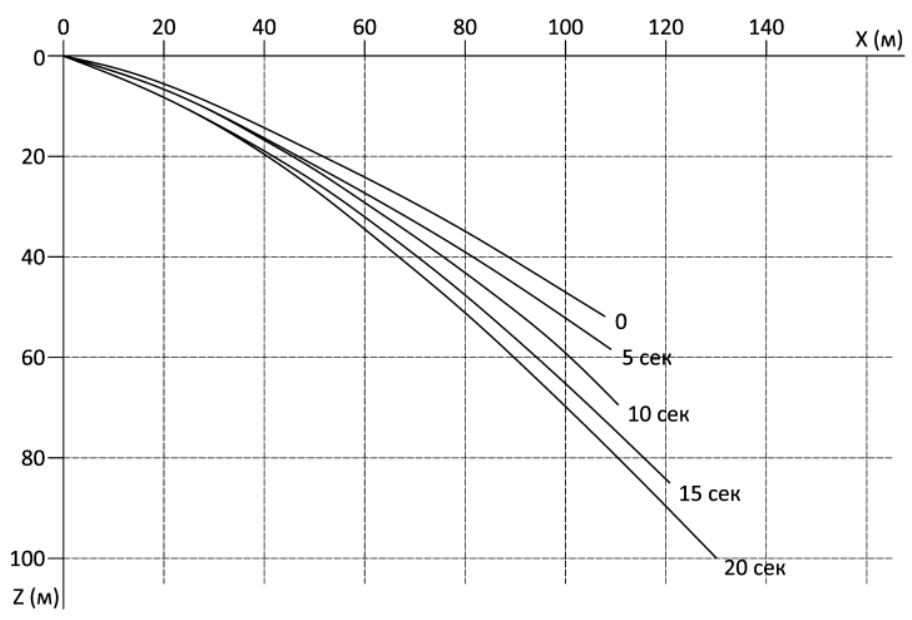

Рис. 7 - Еволюція конфігурації ПС. Час 0-20 с 


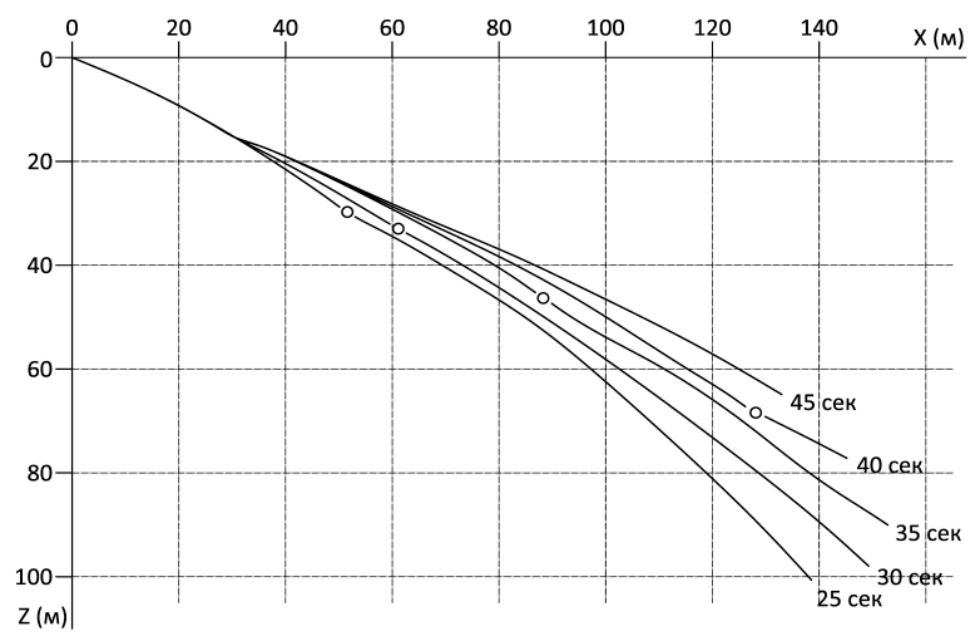

Рис. 8 - Еволюція конфігурації ПС. Час 25-45 с

Для зазначеного режиму тахограми в ПС під час перехідного процесу нелінійно взаємодіють три фізичні процеси, що протікають одночасно, поздовжні хвилі, поперечні хвилі і ефекти, що зумовлені зміною довжини ПС. Характеристикою першого 3 процесів є криві еволюції осьового зусилля i проекції дотичної складової відносної швидкості обтікання канату в потоці. Умовно еволюційну залежність натягу в корінній точці ПС можна розбити на 4 етапи. На першому етапі, під час рівноприскореного змотування ПС із судової лебідки, при збільшенні швидкості змотування осьове зусилля в ПС зменшується. Одночасно з цим збільшується довжина витравленої ії частини, збільшується гідродинамічний опір, ПС спочатку «запізнюється», а потім підтягується і рухається з постійною швидкістю судном-буксирувальником. Це призводить до ривка в ПС і, як наслідок, до різкого збільшення осьового зусилля на другій ділянці тахограми.

На третій ділянці тахограми швидкість змотування рівномірно зменшується і змотування ПС переходить до вибірки канату (намотування на лебідку). Тут осьове зусилля спочатку плавно, а потім більш різко зростає, перевищуючи початкове квазістатичне значення в 3.5-4 рази. Причому, чим вище ефективний модуль Юнга матеріалу канату, тим вище динамічний ривок в протяжній системі. При уповільненні вибірки канату і повній зупинці лебідки силова картина черговий раз змінюється: осьове зусилля зменшується і поступово виходить на нове стаціонарне значення, відповідне новій довжині ПС в 140 м.

Процеси, які характеризуються поперечними хвилями, є більш згладженими. На кривій еволюції кута відхилення корінної точки від вертикалі можна виділити три характерних ділянки відповідно до зміни швидкості змотування. Однак, повної кореляції залежності немає, це обумовлено запізненням в системі через нелінійну взаємодію перерахованих вище трьох процесів і сил гідродинамічного демпфірування.

\section{Висновки}

1. Незважаючи на численні дослідження, проведені в області вивчення статики і динаміки ПС, неясними залишаються багато особливостей їх поведінки: 
проблеми в діагностиці цілісності паль (каверни, шийки, розширення і т.д.), петлеутворення в ПС при буксируванні в космосі, повітрі та водному середовищі, правильний вибір коефіцієнта динамічності при складних маневрах буксирувальника і т.д. Окремим питанням, що вимагає досліджень в області побудови алгоритмів розпаралелювання і паралельних обчислень, $\epsilon$ врахування багатохвильового характеру розповсюдження збурень в ПС.

2. Отримано п'ятимодову математичну модель, що описує нелінійну динаміку ПС в просторово-неоднорідному полі масових і поверхневих сил. Для неї виконуються принципи граничності i гіперболічності, що сформульовані I.T. Селезовим в роботі [11]. У сукупності 3 крайовими і початковими умовами вона може застосовуватися для управління ПС; опису динаміки і статики геометрично і фізично нелінійних космічних зв'язок; стрижневих елементів (лопатей гвинтокрилів, лопаток турбин та ін.); ерліфтних систем великої протяжності для видобутку корисних копалин з дна Світового океану; паль в грунті; канатів кранового обладнання; шахтних підйомників, підвісних канатних доріг; ПС, що буксируються в потоці рідини та газу; підводних електричних кабелів від морських вітроенергетичних установок та підводних кабелів зв'язку; ін.

3. Осьові сили є однією з основних причин пошкодження ПС (підводних кабелів), які складаються зі спіральної броні, оболонки, ізоляції та проводів. На додаток до осьового подовження, коли кабель піддається розтягуючим навантаженням, спіральна броня також створює крутний момент. У глибоководних умовах вплив тиску води на жорсткість кабелю є важливим. В минулому такі дослідження проводилися рідко [2]. Коли кабель розташований на 4000 м нижче рівня моря, пов'язані розтягуючі, скручуючі i стискаючі навантаження можуть знизити жорсткість на розтяг ПС в цілому до 30\%. Таким чином, при аналізі і проектуванні ПС (підводних кабелів) необхідно ретельно враховувати пов'язані ефекти навантажень розтягування, скручування і стискання [2].

\section{СПИСОК ЛІТЕРАТУРИ}

1. AN/ALE-50 Towed Decoy System. Електронний ресурс. Режим доступу: https://www.raytheon.com/capabilities/products/ale50

2. Mechanical behavior of submarine cable under coupled tension, torsion and compressive loads. Режим доступу: https://www.sciencedirect.com/science/article/abs/pii/S002980181 9304470

3. Combination of Acoustics with High Resolution Oceanography. Електронний ресурс. Режим доступу: https://www.researchgate.net/publication/228540255_Combination_ of_Acoustics_with_High_Resolution_Oceanography/figures?lo=1

4. Электродинамические связки - "ЭДС". Електронний ресурс. Режим доступу: http://galspace.spb.ru/index116.html

5. Тимошенко С.П. Колебания в инженерном деле. - М.: Физматгиз, 1959. - 450 с.

6. Воробьев Ю.С., Шорр Б.Ф. Теория закрученных стержней. - Киев: Наук. думка, 1983. $-188 \mathrm{c}$.

7. Воробьев Ю.С. Уточнение уравнений свободных колебаний вращающихся стержней // Рабочие процессы в турбомашинах и прочность их элементов. - Киев: Наук. думка, 1965. - C. 11-27.

8. Hodges D.H. and Dowell E.H. Nonlinear Equations of Motions for the Elastic Bending and Torsion of Twisted Nonuniform Rotor Blades. - NASA TND-7818, 1974. - $52 \mathrm{p}$. 
9. Crespoda Silva M.R.M. and Glynn C.C. Nonlinear flexural-flexural torsional dynamics of in extensional beams. I: Equations of motion // J. Struct. Mech. - 1978. - No. 6. - P. 437-448. 10. Аврамов К.В., Галас О.С., Морачковский О.К., Пьер К. Анализ нелинейных изгибно-изгибно-крутильных колебаний вращающихся закрученных стержней с учетом депланации поперечного сечения // Проблемы прочности, 2009, № 2 C. $112-124$.

11. Selezov, I.T. Development and Application of the Cauchy-Poisson Method to Layer Elastodynamics and the Timoshenko Equation. Cybern Syst Anal 54, 434-442 (2018). DOI: https://doi.org/10.1007/s10559-018-0044-x

12. Kaliukh, I., Fareniuk, G., Trofymchuk, O., Fareniuk, I., Berchun, Y. (2019). Identification of defects in reinforced concrete piles based on multi-wave reflection. In: Derkowski W., Gwoździewicz P., Hojdys Ł., Krajewski P. (eds). Proc. fib Symp. 2019: Concrete Innovations in Materials, Design and Structures, Fédération Internationale du Béton (fib) International Federation for Structural Concrete. - P. 991-998. URL http://www.scopus.com/inward/record.url?eid=2-s2.0-85066103818\&partnerID=MN8TOARS

13. Kaliukh, I., Trofymchuk, O. \& Lebid, O. Numerical Solution of Two-Point Static Problems for Distributed Extended Systems by Means of the Nelder-Mead Method. Cybern Syst Anal 55, 616-624 (2019). DOI: https://doi.org/10.1007/s10559-019-00170-3

14. Trofymchuk, O., Lebid, O., Klymenkov, O., Berchun, Y., Berchun, V., Kaliukh, I., Marjenkov, M., Shekhunova, S., Havriliuk, R. [2019] Dynamic certification of landslide protection structures in a seismically hazardous region of Ukraine: experimental and analytical research. Earthquake geotechnical engineering for protection and development of environment and constructions. In: Silvestri F., Moraci N. (eds.). Proc. of the VII ICEGE 7th International Conference on Earthquake Geotechnical Engineering, Rome, Italy, 17-20 June 2019, 5337-5344.

15. Lebid A.G. (2020) Control and Dynamics of a Distributed System with Variable Length Journal of Automation and Information Sciences, 52(9), 39-50. DOI: 10.1615/JAutomatInfScien.v52.i9.40

16. Trofymchuk, O., Kaliukh, I., \& Klymenkov, O. (2018). TXT-tool 2.380-1.1. Monitoring and Early Warning System of the Building Constructions of the Livadia Palace, Ukraine. In: Sassa K. et al. (eds.) Landslide Dynamics: ISDR-ICL Landslide Interactive Teaching Tools (pp. 491-508). Cham: Springer. DOI: https://doi.org/10.1007/978-3-319-57774-6_37

17. Трофимчук А.Н., Черний В.Г., Черний Г.И. (2006). Надежность систем сооружение грунтовое основание в сложных инженерно-геологических условиях. - Київ. Полграф консалтінг. $-247 \mathrm{c}$.

18. Gorban I.M., Lebid O.G. (2019) Numerical Modeling of the Wing Aerodynamics at Angle-of-Attack at Low Reynolds Numbers. In: Sadovnichiy V., Zgurovsky M. (eds) Modern Mathematics and Mechanics. Understanding Complex Systems. Springer, Cham. https://doi.org/10.1007/978-3-319-96755-4_10

19. Grebenikov, V., Kajan, V., Lebid, O., Pryjmak, M. (2015) Wind power unit the new type wind turbin and electric generator // International Journal of Scientific Engineering and Applied Science (IJSEAS) - Volume-1, Issue-7, October 2015:407-413.

20. Kayan, V.P., Kochin, V.A., Lebid, O.G. (2009) Studying the performance of Vertical Axis Wind Turbine (VAWT) models with blade control mechanism // International Journal of Fluid Mechanics Research, 2009, 36(2), pp. 154-165.

21. Hegemier G.A., Nair S. A nonlinear dynamical theory for heterogeneous, anisotropic, elastic rods // AIAAI. - 1977. - 15, № 1. - P. 8-15.

Стаття надійшла до редакиії 19.02.2021 і прийнята до друку після рецензування 17.05.2021 


\section{REFERENCES}

1. AN/ALE-50 Towed Decoy System. Retrieved 12.02.2021 from: https://www.raytheon.com/capabilities/products/ale50

2. Mechanical behavior of submarine cable under coupled tension, torsion and compressive loads. Retrieved 12.02.2021 from: https://www.sciencedirect.com/science/article/abs/pii/ S0029801819304470

3. Combination of Acoustics with High Resolution Oceanography. Retrieved 12.02.2021 from: https://www.researchgate.net/publication/228540255_Combination_of_Acoustics _with_High_Resolution_Oceanography/figures?lo=1

4. Jelektrodinamicheskie svjazki [Electrodynamic connections]. Retrieved 12.02.2021 from: http://galspace.spb.ru/index 116. html

5. Timoshenko, S.P. (1959). Kolebanija $v$ inzhenernom dele [Fluctuations in engineering]. Moscow: Fizmatgiz (in Russian).

6. Vorob'ev, Ju.S., \& Shorr, B.F. (1983). Teorija zakruchennyh sterzhnej [Theory twisted bars]. Kyiv: Nauk. Dumka (in Russian).

7. Vorob'ev, Ju.S. (1965). Utochnenie uravnenij svobodnyh kolebanij vrashhajushhihsja sterzhnej [Refinement of the equations of free vibrations of rotating rods]. In Rabochie processy $v$ turbomashinah i prochnost' ih jelementov, (pp. 11-27). Kyiv: Nauk. Dumka (in Russian).

8. Hodges, D.H., \& Dowell, E.H. (1974). Nonlinear Equations of Motions for the Elastic Bending and Torsion of Twisted Nonuniform Rotor Blades. NASA TND-7818.

9. Crespoda Silva, M.R.M., \& Glynn, C.C. (1978). Nonlinear flexural-flexural torsional dynamics of in extensional beams. I: Equations of motion. J. Struct. Mech, 6, 437-448.

10. Avramov, K.V., Galas, O.S., Morachkovskij, O.K., \& P'er, K. (2009). Analiz nelinejnyh izgibno-izgibno-krutil'nyh kolebanij vrashhajushhihsja zakruchennyh sterzhnej s uchetom deplanacii poperechnogo sechenija [Analysis of nonlinear flexural-flexural-torsional vibrations of rotating twisted rods taking into account the deplanation of the cross-section]. Problemy prochnosti, 2, 112-124 (in Russian).

11. Selezov, I.T. (2018). Development and Application of the Cauchy-Poisson Method to Layer Elastodynamics and the Timoshenko Equation. Cybern Syst Anal, 54, 434-442. DOI: https://doi.org/10.1007/s10559-018-0044-x

12. Kaliukh, I., Fareniuk, G., Trofymchuk, O., Fareniuk, I., \& Berchun, Y. (2019). Identification of defects in reinforced concrete piles based on multi-wave reflection. In: Derkowski W., Gwoździewicz P., Hojdys Ł., Krajewski P. (eds). Proc. fib Symp. 2019: Concrete - Innovations in Materials, Design and Structures, Fédération Internationale du Béton (FIB) - International Federation for Structural Concrete, (pp. 991-998). URL http://www.scopus.com/inward/record.url?eid=2-s2.0-85066103818\&partnerID=MN8TOARS 13. Kaliukh, I., Trofymchuk, O. \& Lebid, O. Numerical Solution of Two-Point Static Problems for Distributed Extended Systems by Means of the Nelder-Mead Method. Cybern Syst Anal, 55, 616-624. DOI: https://doi.org/10.1007/s10559-019-00170-3

14. Trofymchuk, O., Lebid, O., Klymenkov, O., Berchun, Y., Berchun, V., Kaliukh, I., et al. (2019). Dynamic certification of landslide protection structures in a seismically hazardous region of Ukraine: experimental and analytical research. Earthquake geotechnical engineering for protection and development of environment and constructions. In: Silvestri F., Moraci N. (eds.). Proc. of the VII ICEGE 7th International Conference on Earthquake Geotechnical Engineering, Rome, Italy, 17-20 June 2019, 5337-5344.

15. Lebid, A.G. (2020). Control and Dynamics of a Distributed System with Variable Length. Journal of Automation and Information Sciences, 52 (9), 39-50. DOI: 10.1615/JAutomatInfScien.v52.i9.40

16. Trofymchuk, O., Kaliukh, I., \& Klymenkov, O. (2018). TXT-tool 2.380-1.1. Monitoring and Early Warning System of the Building Constructions of the Livadia Palace, Ukraine. In: Sassa K. et al. (eds.) Landslide Dynamics: ISDR-ICL Landslide Interactive Teaching Tools (pp. 491-508). Cham: Springer. DOI: https://doi.org/10.1007/978-3-319-57774-6_37 
17. Trofimchuk, A.N., Chernij, V.G., \& Chernij, G.I. (2006). Nadezhnost' sistem sooruzhenie gruntovoe osnovanie $v$ slozhnyh inzhenerno-geologicheskih uslovijah [Reliability of systems construction - soil foundation in difficult engineering and geological conditions]. Kyiv: Polgraf konsalting (in Russian).

18. Gorban I.M., \& Lebid O.G. (2019). Numerical Modeling of the Wing Aerodynamics at Angle-of-Attack at Low Reynolds Numbers. In: Sadovnichiy V., Zgurovsky M. (eds) Modern Mathematics and Mechanics. Understanding Complex Systems. Springer, Cham. https://doi.org/10.1007/978-3-319-96755-4_10

19. Grebenikov, V., Kajan, V., Lebid, O., \& Pryjmak, M. (2015). Wind power unit the new type wind turbin and electric generator. International Journal of Scientific Engineering and Applied Science (IJSEAS), 1 (7), 407-413.

20. Kayan, V.P., Kochin, V.A., \& Lebid, O.G. (2009). Studying the performance of Vertical Axis Wind Turbine (VAWT) models with blade control mechanism. International Journal of Fluid Mechanics Research, 36 (2), 154-165.

21. Hegemier, G.A., \& Nair, S. (1977). A nonlinear dynamical theory for heterogeneous, anisotropic, elastic rods. AIAAI, 15 (1), 8-15.

The article was received 19.02.2021 and was accepted after revision 17.05.2021

\section{Лебідь Олексій Григорович}

кандидат технічних наук, старший науковий співробітник, заступник директора Інституту телекомунікацій і глобального інформаційного простору НАНУ

Адреса робоча: 03186 Україна, м. Київ, Чоколівський бульвар, 13

ORCID ID: 0000-0002-4003-8068, e-mail: o.g.lebid@gmail.com 